\title{
Zaburzenia ze spektrum autyzmu i padaczka
}

\author{
Autism spectrum disorders and epilepsy
}

\author{
Barbara Gurda (D), Bogna Malendowicz-Major (iD, Barbara Steinborn (iD) \\ Katedra i Klinika Neurologii Wieku Rozwojowego Uniwersytet Medyczny im. K. Marcinkowskiego w Poznaniu \\ DOI:10.20966/chn.2019.57.445
}

\section{STRESZCZENIE}

Zaburzenia ze spektrum autyzmu (ASD) i padaczka należą do częstych zaburzeń neurologicznych u dzieci. Częstość ich występowania szacuje się na około $1 \%$ populacji. Schorzenia te mogą występować niezależnie lub współwystępować u tej samej osoby, często z towarzyszącymi specyficznymi zaburzeniami neurorozwojowymi oraz niepełnosprawnością intelektualną. Wspótwystępowanie ASD i padaczki jest dobrze znane w literaturze, a występowanie padaczki w ASD szacuje się, wg różnych autorów od $2,7 \%$ do $46 \%$.

Związek między ASD i padaczką jest dwukierunkowy: u pacjentów z rozpoznaniem ASD może rozwinąć się padaczka i odwrotnie u pacjentów z napadami padaczkowymi mogą pojawić się cechy autyzmu. Podkreśla się jednak częstsze występowanie padaczki u pacjentów z ASD $(13,7 \%)$ niż ASD u pacjentów z padaczką $(3,4 \%)$. Istotnym czynnikiem ryzyka w obu przypadkach jest niepełnosprawność intelektualna.

Ryzyko rozwoju padaczki u pacjentów z ASD wynosi wg różnych autorów od $6 \%$ do $46 \%$. W ASD nie odnotowano dominującego typu lub zespołu padaczkowego. Jednak większość badaczy wskazuje na najczęstsze występowanie napadów ogniskowych. Ryzyko rozwoju padaczki jest większe u dzieci starszych oraz u pacjentów z niskim ilorazem inteligencji.

$Z$ drugiej strony u dzieci z rozpoznaną padaczką może również rozwinąć się ASD, wg danych z piśmiennictwa ryzyko wynosi od $3,4 \%$ do $37 \%$, najwyższe u dzieci z wczesnym początkiem i dużą częstością napadów. Większe ryzyko rozwoju ASD istnieje również w różnych zespołach padaczkowych (zespół Westa, zespół Dravet) a także u dzieci z opóźnieniem rozwoju i niepełnosprawnością intelektualną.

W wielu pracach wykazano wspólne mechanizmy patofizjologiczne obu tych schorzeń. Obecność padaczki i ASD może być zdeterminowana zmianami strukturalnymi OUN, czynnikami genetycznymi oraz zaburzeniami metabolicznymi, środowiskowymi i okołoporodowymi, które odgrywają istotną rolę w patogenezie zarówno padaczki jak i autyzmu.

Słowa kluczowe: padaczka, autyzm, ASD, niepełnosprawność intelektualna, EEG

\section{SUMMARY}

Autistic spectrum disorders (ADS) and epilepsy are common pediatric neurological disorders. Prevalence of both is estimated at approximately $1 \%$ in the population. These two disorders can appear separately or coexist in the same person, often with concomitant specific developmental disorders and intellectual disability.

The comorbidity of ASD and epilepsy is well known and the occurrence of epilepsy in ASD ranges, according to various authors, from $2,7 \%-46 \%$.

The relationship between ASD and epilepsy is bidirectional: patients firstly diagnosed with ASD can develop epilepsy, and conversely, children with epileptic seizures can develop autistic symptoms. The recent studies indicate that epilepsy occurrs more frequently in patients with ASD $[13,7 \%]$ than ASD among patients with epilepsy [3,4\%]. The crucial risk factor in both cases is intellectual disability.

The risk of developing epilepsy in patients with ASD according to the literature data ranges from $6-46 \%$. ASD studies indicated that there is no dominant type or epilepsy syndrome. However, most scientists indicate that partial seizures are the most commonly reported. The risk of developing epilepsy is greater in the older children and in patients with lower IO.

On the other hand, children firstly diagnosed with epilepsy can also develop ASD; according to published data the risk is from $3,4 \%-37 \%$, the highest among children with the early onset and with frequent seizures. The higher risk of ASD is also related to other various epileptic syndromes (infantile spasms, Dravet syndrom) and in children with developmental disorders and intellectual disability.

In many works, common pathophysiological mechanisms have been shown to underlie both of these diseases Appearance of both could be determined by structural abnormalities in CNS, genetic and environmental factors, metabolic disorders or perinatal injuries.

Key words: epilepsy, autism, ASD, intellectual disability, EEG
Zaburzenia ze spektrum autyzmu (autistic spectrum disorders ASD) to coraz częściej rozpoznawane biologiczne zaburzenia neurorozwojowe charakteryzujące się upośledzeniem komunikacji i interakcji społecznych oraz stereotypowością zachowań i zainteresowań, występują u 0,75\% do $1,1 \%$ populacji $[1,2]$. Padaczka $\mathrm{z}$ różnymi rodzajami napadów pojawia się u około $0,4 \%$ do $0,8 \%$ populacji [3]. Współistnienie obu tych zespołów chorobowych no- tuje się od ponad 50 lat i stało się przedmiotem licznych analiz i doniesień. Obecność jednego schorzenia znacznie zwiększa prawdopodobieństwo wystąpienia drugiego zaburzenia.

Związek między ASD i padaczką jest dwukierunkowy: $\mathrm{u}$ pacjentów $\mathrm{z}$ pierwotnym rozpoznaniem ASD może rozwinąc się padaczka, z drugiej strony u pacjentów z napadami padaczkowymi mogą pojawić się cechy autyzmu. Pod- 
Tab. I. Współwystępowanie padaczki i ASD na podstawie danych z piśmiennictwa

Tab. I. Co-occurence of epilepsy and ASD on the basis of the published data

\begin{tabular}{|c|c|l|}
\hline $\begin{array}{c}\text { Pacjenci z pierwotnie rozpoznanym ASD } \\
\text { i padaczą } \\
\text { Patients with primary ASD and epilepsy }\end{array}$ & $\begin{array}{c}\text { Pacjenci z pierwotnie rozpoznaną padaczką } \\
\text { i ASD } \\
\text { Patients with primary epilepsy and ASD }\end{array}$ & \multicolumn{1}{c|}{$\begin{array}{c}\text { Autorzy } \\
\text { Authors }\end{array}$} \\
\hline $13,7 \%$ & $3,4 \%, 6,3 \%$ & Strasser i wsp. [3] \\
\hline $6 \%-27 \%$ & $5 \%-37 \%$ & Jeste i Tuchman [1, 4] \\
\hline $12,5 \%-26 \%$ & & Viscidi i wsp. [6] \\
\hline $2,7 \%-44,4 \%$ & & Buckley i Holmes [7] \\
\hline $5 \%-46 \%$ & $15,2 \%$ & Pacheva i wsp. [2] \\
\hline & $5 \%-37 \%$ & Matsuo i wsp. [8] \\
\hline & & Berg i Plioplys [5] \\
\hline $8,6 \%$ & & Thomas i wsp. [9] \\
\hline
\end{tabular}

w tym miejscu zaznaczono usunięcie

wyrazów, ale wtety zdanie traci sens

kreśla się jednak częstsze występowanie padaczki u pacjentów z wcześniej rozpoznanym ASD (13,7\%) niż ASD u pacjentów z padaczką (3,4\%) [3]. W tabeli I przedstawiono przegląd danyeh statystyeznyeh $\mathrm{z}$ piśmiennictwa dotyczących współwystępowania padaczki i ASD. Kluczowym czynnikiem ryzyka jest niepełnosprawność intelektualna. Dzieci z padaczką i niepełnosprawnością intelektualną są znacznie bardziej narażone na wystąpienie autyzmu niż dzieci z padaczką o prawidłowym intelekcie [5]. W wielu pracach autorzy podają współwystępowanie triady nakładających się na siebie zaburzeń: padaczka + autyzm + niepełnosprawność intelektualna [3-5].

\section{RYZYKO ROZWOJU PADACZKI W ASD}

Na podstawie danych z piśmiennictwa częstość rozwoju padaczki w ASD jest różna. Ryzyko padaczki u osób z rozpoznaniem ASD wynosi 6-27\% [1, 4]. Wg innych autorów $[6,10,11]$ średnia częstość występowania padaczki u dzieci z ASD w wieku 2-17 lat w badaniach z ostatnich lat wynosiła $12,5 \%$, a w grupie dzieci w wieku 13 lat i starszych $26 \%$. U osób z ASD odnotowano dwa okresy ze zwiększoną częstością napadów. Jeden we wczesnym dzieciństwie i drugi w wieku dojrzewania i późniejszym. Wg Buckley i Holmes [7] ryzyko rozwoju padaczki u osób z ASD szacuje się na $2,7 \%$ do $44,4 \%$ w stosunku do populacji ogólnej, a w doniesieniu Pacheva i wsp. [2] 5\%-46\%. Większe ryzyko wystąpienia napadów obserwowano u pacjentów z niższą zdolnością poznawczą, gorszym funkcjonowaniem adaptacyjnym i językowym, niepełnosprawnością intelektualną, oraz wg Viscidi i wsp. [6] w cięższych postaciach ASD. Podkreśla się istotny związek współistniejącej niepełnosprawności intelektualnej, która w znacznym stopniu przyspiesza pojawienie się padaczki w ASD [11, 12]. Częstość występowania napadów w ASD w zależności od stopnia niepełnosprawności obrazuje tabela II.

Innym czynnikiem ryzyka rozwoju padaczki u osób z ASD jest wiek. Częstość pojawienia się napadów wzrasta z wiekiem, z najwyższym szczytem we wczesnym okresie dojrzewania. W populacji dzieci, u których zdiagnozowano ASD w pierwszej dekadzie życia, większość napadów rozwija się po 10 roku życia a ryzyko rozwoju padaczki nadal wzrasta do trzeciej dekady życia $[1,4,13]$. Kolejne czynniki ryzyka wg niektórych badaczy to płeć żeńska, niższy status społeczno-ekonomiczny oraz wywiad rodziny w kierunku ASD.

Tab. II. Występowanie napadów padaczkowych w ASD w zależności od stopnia niepełnosprawności intelektualnej [1] Tab. II. Prevalence of epileptic seizures in ASD depending on intelectual disability [1]

\begin{tabular}{cc}
\hline $\begin{array}{c}\text { Niepełnosprawność } \\
\text { intelektualna - wartość IQ } \\
\text { Intellectual disabillity (IQ) }\end{array}$ & $\begin{array}{c}\text { Padaczka - odsetek } \\
\text { chorych } \\
\text { Epilepsy - percentage } \\
\text { of patients }\end{array}$ \\
\hline $10>70$ & $8 \%$ \\
\hline $10<70$ & $21,4 \%$ \\
\hline $10<40$ & $46 \%$ \\
\hline
\end{tabular}

\section{RODZAJE NAPADÓW PADACZKOWYCH U DZIECI Z ASD}

$\mathrm{W}$ badaniach grup chorych z ASD nie odnotowano dominującego typu lub zespołu padaczkowego. U pacjentów tych mogą występować prawie wszystkie rodzaje napadów. Jednak w większości opracowań stwierdzono częstsze występowanie napadów ogniskowych w porównaniu z uogólnionymi $[2,3,14]$. Typy napadów występujących w ASD przedstawiono w tabeli III. Nasilenie częstości napadów padaczkowych jest bardzo zmienne. Niektórzy autorzy podają występowanie napadów opornych na leczenie u $1 / 3$ pacjentów [15]. Największym jednak wyzwaniem w rozpoznaniu napadów padaczkowych i padaczki jest interpretacja stanów napadowych, licznych stereotypii, zahamowań ruchowych i zachowań charakterystycznych dla ASD.

Istnieje wiele doniesień o zmianach w EEG u dzieci z autyzmem. Nieprawidłowości w zapisie EEG występują częściej u dzieci z ASD niż u dzieci prawidłowo rozwijających się. Zmiany w EEG, najczęściej o charakterze ogniskowym obserwuje się zarówno u pacjentów z rozpoznaną jak i bez rozpoznania padaczki [16]. Wyładowania padaczkowe opisano u $35 \%$ do $86 \%$ pacjentów z autyzmem i padaczką. Natomiast u dzieci z autyzmem bez napadów kli- 
Tab. III. Typy napadów padaczkowych u pacjentów z ASD i padaczką $[2,15,22]$

Tab. III. Type of seizures in patients with ADS and epilepsy $[2,15,22]$

\begin{tabular}{lll}
\hline \multicolumn{1}{c}{$\begin{array}{c}\text { Typ napadów } \\
\text { Type of seizures }\end{array}$} & $\%$ & \multicolumn{1}{c}{$\begin{array}{c}\text { Autorzy } \\
\text { Authors }\end{array}$} \\
\hline Napady ogniskowe bez lub & 53,4 & Pacheva i wsp. [2] \\
z wtórnym uogólnieniem & 55 & $\begin{array}{l}\text { Danielsson i wsp. [22] } \\
\text { Sansa i wsp. [15] }\end{array}$ \\
\hline Napady uogólnione & 26,9 & Pacheva i wsp. [2] \\
& 21 & Danielsson i wsp. [22] \\
& 22 & Sansa i wsp. [22] \\
\hline Napady mieszane & 15,4 & Pacheva i wsp. [2] \\
(ogniskowe i uogólnione) & 12 & Danielsson i wsp. [22] \\
\hline Napady nieskasyfikowane & 12 & Danielsson i wsp. [22] \\
\hline Poprzedzające napady & 11,5 & Pacheva i wsp. [2] \\
zgięciowe & & \\
\hline
\end{tabular}

nicznych odsetek nieprawidłowych zapisów EEG wg Pacheva i wsp. [2] wynosi 28,6\%, w badaniu Spence i Schneider [17] 30\%, a w innych opracowaniach nawet do $60 \%$. Z kolei w badaniu Rossi i wsp. [18] opisano występowanie zmian napadowych w EEG u 18,9\% chorych z ASD bez rozpoznanej padaczki, jest to znacznie wyższy odsetek niż w populacji ogólnej (1,1 do 6,8\% a u dzieci 2,4 do 3,5\%) [19]. Opisuje się zarówno niespecyficzne zmiany takie jak spowolnienie lub asymetria jak i wyładowania padaczkowe. Niektórzy badacze sugerują częstsze występowanie nieprawidłowości znad okolic czołowych [8]. Obecność napadów padaczkowych oraz nieprawidłowości w EEG u pacjentów z ASD może w konsekwencji prowadzić do regresu funkcji poznawczych i zaburzeń zachowania.

\section{RYZYKO ROZWOJU ASD W PADACZCE}

Padaczka może powodować poważne zaburzenia neurorozwojowe predysponujące do pojawienia się ASD. Wczesne epizody napadowe wywołują trwałe deficyty fizjologiczne i funkcjonalne w hipokampie, zaburzenia synaptyczne oraz dysfunkcję neuronów korowych. Ryzyko rozwoju ASD u dzieci z padaczką wg danych z różnych doniesień jest zmienne i wynosi 6,3\% [3] lub 5\%-37\% [1,4] i jest najwyższe u dzieci z wczesnym początkiem i dużą częstością napadów. Odnotowano największe ryzyko rozwoju ASD u dzieci z drgawkami przed drugim rokiem życia. Stwierdzono, że $80 \%$ dzieci z rozpoznaniem ASD i padaczki miało napady padaczkowe w pierwszym roku życia [3]. Również w różnych zespołach padaczkowych (zespół Westa, zespół Dravet) istnieje większe ryzyko rozwoju ASD $[3,20]$. Jednym $z$ powodów jest to, iż zarówno objawy w zespole Westa jak i Dravet pojawiają się w pierwszym roku życia, co jak wcześniej wspomniano stanowi istotny czynnik rozwoju ASD w padaczce. W badaniu oceniającym występowanie napadów padaczkowych z początkiem w pierwszym roku życia zaobserwowano, że u 35\% dzieci z zespołem Westa rozwinął się autyzm w porównaniu z 9\% z innymi rodzajami padaczki [20].
Kolejnym czynnikiem ryzyka rozwoju ASD w padaczce jest opóźnienie rozwoju oraz niepełnosprawność intelektualna. W licznych opracowaniach potwierdzono silne powiązanie rozwoju ASD w padaczce z niepełnosprawnością intelektualną $[1,4]$.

W tabeli IV przedstawiono dane z opracowania Strasser i wsp. [3] obrazujące wystąpienie ASD w grupie badanej w zależności od wieku, rodzaju padaczki oraz niepełnosprawności intelektualnej.

Tab. IV. Występowanie zaburzeń ze spektrum autyzmu w zależności od wieku, rodzaju padaczki, niepełnosprawności intelektualnej [3]

Tab. IV. Prevalence for autism spectrum disorders depending on age, type of epilepsy and intellectual disability [3].

\begin{tabular}{lc}
\hline & $\begin{array}{c}\text { Obecność ASD\% (od-do) } \\
\text { Presence of ASD\% (range) }\end{array}$ \\
\hline Ogółem & $6,3 \%(5,4-7,1)$ \\
\hline Wiek & $22,4(16,3-28,5)$ \\
$<18$ & $1,7(1,3-2,2)$ \\
$>18$ & \\
\hline Typ padaczki & $4,7 \%(4,0-5,6)$ \\
Napady uogólnione & $19,9 \%(8,0-31,7)$ \\
Napady skłonów & $41,9 \%(31,4-50,3)$ \\
Napady ogniskowe & $47,4 \%(20,7-74,3)$ \\
Zespół Dravet & \\
& \\
\hline Niepełnosprawność & \\
intelektualna & $5,2 \%(3,2-7,1)$ \\
Poniżej 50\% badanych & $25,4 \%(18,1-32,9)$ \\
Ponad 50\% badanych & $16,9 \%(5,3-28,4)$ \\
Nieokreślona & \\
\hline
\end{tabular}

\section{JAKIE MECHANIZMY LEŻĄ U PODSTAWY WSPÓtWYSTĘPOWANIA ASD I PADACZKI?}

Wg danych z literatury u podłoża obu tych schorzeń leżą wspólne mechanizmy patofizjologiczne. Obecność padaczki i ASD może być zdeterminowana zmianami strukturalnymi OUN, czynnikami genetycznymi oraz zaburzeniami metabolicznymi, środowiskowymi i okołoporodowymi, które odgrywają istotną rolę w patogenezie zarówno padaczki jak i autyzmu.

Wykazano, że czynniki genetyczne odgrywają ważną rolę w patogenezie ASD i padaczki. Zidentyfikowano szereg mutacji genowych oraz aberracji chromosomalnych stanowiących przyczynę ASD, padaczki oraz towarzyszącej niepełnosprawności intelektualnej. Opisano liczne zespoły genetyczne ze zwiększonym ryzykiem rozwoju zarówno ASD jak i padaczki w porównaniu z populacją ogólną. Wg Buckley i Holmes[7] w zespole Angelmana ASD występuje u 1,9-42\% badanych, padaczka u $85-100 \%$; w zespole Corneli de Lange odpowiednio 32-65\% badanych i $23-26 \%$. Z kolei w zespole Dravet ASD stwierdzono u 24,3\%-61,5\% a padaczkę u 100\% pacjentów, w zespole Downa ASD u 3,1-18,2\% a padaczkę u $1-13 \%$ badanych (tab. V).

Zaburzenia molekularne pociągają za sobą zmiany w zakresie synaptogenezy, funkcji interneuronów, dys- 
regulację szlaku mTOR, zaburzenia funkcji receptorów GABA i NMDA oraz kanałów sodowych. Te wielorakie uszkodzenia połączeń i szlaków są wspólne dla ASD i padaczki oraz dla niepełnosprawności intelektualnej, co tłumaczy ich współwystępowanie [1].

Tab. V. Zespoły genetyczne z ASD oraz współistniejąca padaczką [7]

Tab. V. Genetic syndromes with ASD and coexisting epilepsy [7]

\begin{tabular}{lcc}
\hline \multicolumn{1}{c}{$\begin{array}{c}\text { Zespół } \\
\text { Syndrome }\end{array}$} & $\begin{array}{c}\text { Odsetek z ASD } \\
\text { Percent } \\
\text { with ASD }\end{array}$ & $\begin{array}{c}\text { Odsetek z padaczką } \\
\text { Percent } \\
\text { with epilepsy }\end{array}$ \\
\hline $\begin{array}{l}\text { Zespół } \\
\text { Angelmana }\end{array}$ & $1,9 \%-42 \%$ & $85 \%-100 \%$ \\
\hline $\begin{array}{l}\text { Zespół Cornelia } \\
\text { de Lange }\end{array}$ & $32 \%-65 \%$ & $23 \%-26 \%$ \\
\hline Zespół Downa & $3,1 \%-18,2 \%$ & $1 \%-13 \%$ \\
\hline Zespół Dravet & $24,3 \%-61,5 \%$ & $100 \%$ \\
\hline Zespół FraX & $21 \%-30 \%$ & $11,8 \%-18 \%$ \\
\hline $\begin{array}{l}\text { Stwardnienie } \\
\text { guzowate }\end{array}$ & $10,8 \%$ & $70 \%-80 \%$ \\
\hline
\end{tabular}

Wśród czynników neurobiologicznych należy wymienić zmiany strukturalne ośrodkowego układu nerwowego oraz zaburzenia połączeń neuronalnych $\mathrm{z}$ nieprawidłowym ich funkcjonowaniem. W porównaniu $\mathrm{z}$ grupą osób zdrowych u dzieci z ASD i padaczką występują nieprawidłowości w zakresie budowy kory mózgowej (heterotopie, dysplazje korowe $\mathrm{i}$ in.), zaburzenia objętości istoty szarej i białej, zaburzenia sieci neuronalnej i neuroprzekaźników [21].

Wśród czynników środowiskowych i okołoporodowych wymienia się czynniki toksyczne, teratogenne, urazy i infekcje okołoporodowe.

Z innych czynników przyczynowych opisywane są choroby matki podczas ciąży (np. nadciśnienie, cukrzyca, otyłość) i przyjmowane leki oraz starszy wiek rodziców.

$\mathrm{Na}$ podstawie metaanalizy badań przeprowadzonych $\mathrm{u}$ dzieci z autyzmem i padaczką przedstawiono nieliczne dowody wpływu pojedynczego czynnika na etiologię i patogenezę obu schorzeń $[3,6,21]$, wskazano na istnienie zwykle kilku nakładających się na siebie elementów.

\section{PODSUMOWANIE}

Na podstawie przeglądu piśmiennictwa wykazano istotny związek ASD z padaczką przy czym stwierdzono częstsze występowanie padaczki u pacjentów z pierwotnym ASD $(13,7 \%)$ niż ASD u pacjentów z wcześniej rozpoznaną padaczką $(3,4 \%)$. Napady padaczkowe u dzieci z ASD mają najczęściej charakter ogniskowy. Istotnym czynnikiem ryzyka w obu przypadkach jest niepełnosprawność intelektualna. Również wiek stanowi ważny element ryzyka: u pacjentów z ASD częstość pojawienia się napadów wzrasta z wiekiem z najwyższym szczytem we wczesnym okre- sie dojrzewania, natomiast ryzyko rozwoju ASD u dzieci z padaczką jest największe we wczesnych zespołach padaczkowych oraz w przypadku wystąpienia drgawek w pierwszym roku życia. Wg danych z literatury wykazano wspólne mechanizmy patofizjologiczne obu schorzeń, przede wszystkim podłoże genetyczne, a także przyczyny metaboliczne, zmiany strukturalne ośrodkowego układu nerwowego, czynniki środowiskowe i okołoporodowe.

\section{PIŚMIENNICTWO}

[1] Tuchman R.: What is the relationship between autism spectrum disorders and epilepsy? Semin Pediatr Neurol 2017; 24: 292-300.

[2] Pacheva I., Ivanov I., Yordanova R., et al.: Epilepsy in Children with Autistic Spectrum Disorder. Children (Basel). 2019; 6: 15.

[3] Strasser L., Downes M., Kung J. et al.: Prevalence and risk factors for autism spectrum disorder in epilepsy: a systematic review and metaanalysis. Dev Med Child Neurol 2018; 60: 19-29.

[4] Jeste S.S., Tuchman R.: Autism spectrum disorder and epilepsy: two sides of the same coin? J Child Neurol. 2015; 30: 1963-1971.

[5] Berg A.T., Plioplys S.: Epilepsy and autism: Is there a special relationship? Epilepsy Behav. 2012; 23: 193-198.

[6] Viscidi E.W., Triche E.W., Pescosolido M.F., et al.: Clinical characteristics of children with autism spectrum disorder and co-occuring epilepsy PLoSONE 2013; 8: e67797.

[7] Buckley A.W., Holmes G.L.: Epilepsy and autism. Cold Spring Harb Perspect Med. 2016; 6: a022749

[8] Matsuo M., Maeda T., Sasaki K.: Frequent association of autism spectrum disorders in patients with childhood onset epilepsy. Brain Dev 2010; 32: 759-763.

[9] Thomas S., Hovinga M.E. Rai D., et al.: Brief report: prevalence of cooccuring epilepsy and autism spectrum disorder: the US national survey of children`s health 2011-2012. J Autism Dev Disord., 2017; 47: 224-229.

[10] Dworzańska E., Makarewicz A., Koncewicz R., et al.: Zaburzenia neurologiczne w autyzmie. Zdrowie i dobrostan 2015; I: 37-44.

[11] Hara H.: Autsim and epilepsy: A retrospective follow-up study. Brain Dev. 2007; 29: 486-490.

[12] Amiet C., Gourfinkel-An I., Bouzamondo A., et al.: Epilepsy in autism is associated with intellectual disability and gender: evidence from a metaanalysis. Biol Psychiatry. 2008 0ct 1; 64: 577-582.

[13] Zhang W., Baranek G., Boyd B.: Brief Repart: Factors associated with Emergency Department visits for epilepsy among children with autism spectrum disprder. Journal of Autism and Developmental Disorders 2018; 48: 1854-1860.

[14] Ko C., Kim N., Kim E. et al.: The effect of epilepsy on autistic symptom severity assessed by the social rsponsiveness scale in children with autism spectrum disorders Behav Brain Funct. 2016; 12: 20.

[15] Sansa G., Carlson C., Doyle W., et al.: Medically refractory epilepsy in autism. Epilepsia 2011, 52: 1071-1075.

[16] Michalska J., Malendowicz-Major B., Steinborn B.:Obraz czynności bioelektrycznej mózgu w autyźmie dziecięcym Neurol. Dziec. 2019; 57.

[17] Spence S.J., Schneider M.T.: The role of epilepsy and epileptiform EEGs in autism spectrum disorders. Pediatr Res. 2009; 65: 599-606.

[18] Rossi P.G., Posar A., Parmeggiani A.: Epilepsy in adolescents and young adults with autistic disorder. Brain Dev. 2000; 22: 102-106.

[19] Cavazzuti G.B., Cappella L., Nalin A.: Longitudinal-study of epileptiform eeg patterns in normal-children. Epilepsia. 1980; 21: 43-55.

[20] Saemundsen E., Ludvigsson P., Rafnsson V.: Risk of autism spectrum disorders after infantile spasms: A population-based study nested in a cohort with seizures in the first year of life. Epilepsia 2008: 49; 1865-1870.

[21] Augustyn M.: Autism spectrum disorder: terminology, epidemiology and pathogenesis. Literature review current through 2020. https://www.uptodate.com/contents/autism-spectrum-disorderterminology-epidemiology-and-pathogenesis.

[22] Danielsson S., Gillberg C., Billstedt E., et al.: Epilepsy in young adults with autism: a prospective population-based follow-up study of 120 individuals diagnosed in childhood. Epilepsia 2005; 46: 918-923. 